\title{
Alternatives to the Culture of Consumerism, or the Charm of Skeptical Solitude
}

\author{
LINA VIDAUSKYTE் \\ Vilnius University, Universiteto St. 3, 01513 Vilnius \\ Email: lina.vidauskyte@fsf.vu.It
}

\begin{abstract}
The paper focuses on the elaboration of an opposition to the consumer commodity market which is recognised as a sovereign by British sociologist Zygmunt Bauman. For Bauman, consumerism is an archetype of loneliness, and besides the question of alternative to consumerism, there shows up the question of communication. Odo Marquard insists that a modern man experiences inauthentic loneliness and, in fact, he lost an ability to be alone in a positive sense. Loneliness gives us a perfect distance for a sober evaluation of reality and ourselves. In this article skeptical loneliness, among other forms of positive loneliness, is considered as freedom from all dogmas and the wishes of consumers, and as an opposition to a sovereign in the form of the consumer commodity market.
\end{abstract}

Keywords: sovereign, consumerism, market, skepticism, solitude, communication

\section{INTRODUCTION}

When reading Zygmunt Bauman's book Consuming Life, a reader has a feeling that the consumer commodity market gradually acquires the status of an absolute sovereign. It is indeed true that the market is all-powerful, consumerism - as an uninterrupted stream of liquid modernity - carries everything with it. In this flow all spheres of human life are affected: it is life in debt, permanent consumption of commodities, insuperable plastic surgery to maintain good appearance in order to sell himself successfully and become famous, influential, rich, etc. Finally, Bauman himself writes about the market as a sovereign:

'If one agrees with Carl Schmitt's proposition that the ultimate, defining prerogative of sovereign is the right to exempt, then one must accept that the true carrier of sovereign power in the society of consumers is the commodity market; it is there, at the meeting place of sellers and buyers, that selecting and setting apart the damned from the saved, insiders from outsiders, the included from the excluded (or, more to the point, right-and-proper consumers from flawed ones) is daily performed' (Bauman 2007: 65).

It is obvious that the influence of the market, which Bauman describes by using the concepts of political science, is powerful, and in some cases he simply regrets that this unusual sovereign expels the unbelievers from its own 'state' because they do not have the right to live together with the successful people. Bauman writes: 'The consumer commodity market, one has to admit, makes a peculiar, bizarre sovereign, starkly distinct from those familiar 
to the readers of political science tracts. This strange sovereign has neither legislative nor executive agencies, not to mention courts of law - which are rightly viewed as the indispensable paraphernalia of the bona fide sovereigns explored and described in political science textbooks' (Bauman 2007: 65). Unfortunately, Bauman almost does not analyse the 'unhappy' people who fell out of this stream. It seems that for Bauman, they simply appear like a peripheral element that emphasizes the impact of a market economy: the market is not all friendly. At the same time the reader has a feeling that there is no way out of this madness. Everything, including human relations - conversations, love, and even family dinner - are the commodities for consumption. That means the power of an absolute sovereign, or paraphrasing Hans Blumenberg, the myth of the commodity market comes to his end: there is no longer anyone to ask. In this situation, lack of division of powers is a very remarkable fact (e.g. Blumenberg 1985: 3-33).

With regard to the optics which was set above, it is very interesting to note that a contemporary theologist Harvey Cox published the book The Market as God about business theology, the focus of which is the deification of the market, what proves the using of specific metaphors, as, for example, 'the invisible hand' God-like, and the Creator of persons (corporations), God-like (Cox 2016). Thus, different access to the consumer commodity market confirms the same conclusion that the market is the one ruler. In other words, there is a single 'monarch' with a significant aspect of political theology (e.g. Schwarzkopf 2011).

This strange situation, however, proves that the escape from 'the state of the market' is not very complicated, especially considering the situation of previous ages, before the heyday of the market economy and the culture of consumerism (e.g. serfdom or slavery). A number of sociologists repeat that we should be grateful to capitalism for tolerance, because the business is only concerned about money but not the colour of the skin of a business partner or a user, etc. Nevertheless, what does it mean to be in the situation out of the consumer commodity market? What can such a lonely position provide to the 'not discerning/choosing subjects' (Bauman 2007: 65)? If we are already talking about the situation of loneliness, this in itself is a question of communication which, among other problems, is an objective of this article. In order to substantiate my position, I will use the ideas of the contemporary German philosopher Odo Marquard (1928-2015). His position can be considered as the second way of resistance to the consumer commodity market, or, in other words, - to the capitalistic system of exploitation (the first way is the direct and practical opposition, an establishment of a new order; e.g. Bielskis 2014: 146-150).

Marquard's skeptical ideas have been developed as a controversy to Jürgen Habermas's communication theory. As it is well known, Habermas presents communication theory as an alternative to metaphysics. In simple terms, I dare to say that the main focus of the Habermasian theory is disclosed by asking the following question: What are the conditions for global communication? Immanuel Kant, instead of metaphysics or ontology, develops 'the critique of pure reason', while Habermas establishes 'communicative action', as post-metaphysical philosophy (Habermas 1984, 1987). Marquard, however, is against modern cultural complaints that people feel lonely, and therefore everyone should communicate. He ironically appreciates the popular criticism of culture, according to which modernity 'condemns' a person to solitude. Marquard emphasizes that the problem of modern culture is not loneliness but the absence of loneliness. Actually, we are on the way to losing our capacity for loneliness. In his article Plädoyer für die Einsamkeitsfähigkeit the philosopher insists that loneliness is a necessary consequence of the modern bourgeois world (Marquard 1995: 110-111). So, it is pointless to 
struggle with this. On the contrary, it is necessary to agree with loneliness, at least to the extent that it allows us to determine the distance that is necessary in order to provide a more sober assessment of reality (Marquard 1995: 111-112). Finally, Marquard distinguishes the phenomenon that in principle cannot free us from loneliness, but can help to form a cultural capacity for solitude.

\section{SOLITUDE IN MODERNITY}

At the beginning Marquard cites a sentence from the Bible (Genesis 2.18): The LORD God said, 'It is not good for the man to be alone' (Marquard 1995: 110). Being alone means loneliness and even God says that it is not the most appropriate situation for a person. Perhaps the first modern complaint about loneliness is the last work of Jean-Jacque Rousseau Réveries $d u$ promeneur solitaire (1782). As it is well known, Rousseau wrote his last work in isolation, tired and drowned by real and imaginary enemies. In the First Walk we read:

'I am now alone on earth, no longer having any brother, neighbor, friend, or society other than myself. The most sociable and the most loving of humans has been proscribed from society by a unanimous agreement. In the refinements of their hatred, they have sought the torment which would be cruellest to my sensitive soul and have violently broken all the ties which attached me to them. I would have loved men in spite of themselves. Only by ceasing to be human, have they been able to slip away from my affection. They are now strangers, unknowns, in short, nonentities to me - because that is what they wanted. But I, detached from them and from everything, what am I? That is what remains for me seek' (Rousseau 1992: 1).

And since then, the complaint of solitude has never disappeared and has not lost its relevance. Quite the opposite: loneliness is becoming a widespread public evil (Marquard 1995: 111). According to Marquard, not only the title of the text indicates loneliness (walking in solitude), but also the word 'a dreamer' gives important information about the ontological being of a lonely walker. In fact, Rousseau describes his lonely walks in nature and in the end he gradually gets used to loneliness and feels happy, and that is the main point for Marquard's critical position, as we will see it later. But before we start to follow the argumentation of Marquard, nolens volens we should remember a well-known nickname for New York City - The City That Never Sleeps, famously employed in the theme from New York, New York, covered by Frank Sinatra. Does the nickname mean that the nightlife of cities, and especially of big capitals, is an attempt to avoid loneliness? An ancient philosopher Heraclitus in his famous proposition noticed: 'The waking have one common world, but the sleeping turn aside each into a world of his own' (DK B89). Our world is common only when we do not sleep, but when we are asleep, we have our own worlds. But the modern world is in an era of loneliness, insists Marquard. He is convinced that we do not have to worry about our loneliness - actually, the only one fact can be a cause of worry - we cannot be alone at all because we lost the ability to be alone, the art of life disappeared, which would allow us to positively accept loneliness. Thus, the real misfortune of our time is the lack of capacity for solitude. Marquard repeats many times, while stressing that we live in an era of loneliness, and for this there are many reasons. At first, he notes that in our time 'a collapse' of individuality leads to isolation. This is quite elementary: more and more people are living in a small space, and this means that people become closer to each other, but psychologically they feel far from one the other (Marquard 1995: 112). Such farness is a necessary modern phenomenon because only when you do not know anything about your own mass of neighbours, you can live normally. Thus, life in the crowd becomes anonymous: in the crowd, in the overpopulated town an individual 
becomes invisible and lonely; a person no longer knows his neighbours, he is not interested in anyone who is alive or dead. With the increase in the number of people, the intensity of personal communication decreases, and then loneliness appears. This contributes to the growth of the mobility of the modern world which, from the point of view of space, restricts family, good-neighbourly, friendly relations (Marquard 1995: 112). The growth of loneliness in modernity is a transformation of non-loneliness and this refers to the transformation of the majority, which is either the community of some (Mehrsamkeit) or the community of all (Allsamkeit): or it is a group of 'we' that includes only some (e.g. only family members) or such 'we', which includes all people (e.g. all users of commodities). In modernity, the era of universalization, the community of some (Mehrsamkeit) is increasingly replaced by the community of all (Allsamkeit). However, in the unity of all people, anyone can be replaced by another one, but, on the contrary, this cannot happen in the case of the community of some. The exclusiveness of a person becomes indifferent and unnecessary (Marquard 1995: 113). Now people can experience their singularity only as loneliness. Consequently, the rise of modern emancipation from the community of 'some' and the emergence of the community of 'all' inevitably breed loneliness. In this sense, Marquard speaks the same way as Bauman - the importance of communication is revealed in consumption. But Bauman insists that consumption is loneliness: 'Consumption is a supremely solitary activity (perhaps even the archetype of solitude), even when it happens to be conducted in company' (Bauman 2007: 78). Marquard's analysis of different groups of 'all' is similar to a group of consumers which Bauman indicates as a swarm and which is considered to be the opposite of a group based on a different common background. Of course, here is the problem of concepts, but the essence is the same: in addition to the problem of consumption, the problem of communication goes hand in hand. Bauman writes: 'Swarms, unlike groups, know nothing of dissenters or rebels - only, so to speak, of "deserters", "blunderers" or "maverick sheep". Units falling out of the main body in flight have just "strayed", been "lost" or have "fallen by the wayside". They are bound to forage on their own, but the lives of solitary mavericks will seldom last long, because the chance of finding a realistic target by themselves is much smaller than if they follow a swarm, and when fanciful, useless or dangerous targets are pursued, the risks of perishing multiply. The society of consumers tends to break up groups or make them eminently fragile and fissiparous, favouring instead the prompt and swift formation and scattering of swarms' (Bauman 2007: 77). Thus, the lives of single wolves are not long because they have no goals, Bauman says, and in doing so, he generally eliminates any opposition to the market: the opposition does not live long. Is it really a lonely wolf's life so useless?

\section{COMMUNICATION AGAINST LONELINESS}

What the modern individual can do in the face of loneliness? Marquard states that desperate attempts to rebel against loneliness make a person even more lonely. Communication in order to avoid loneliness, mandatory communication is a part of a larger system (Marquard 1995: 114). According to Marquard, there are two phenomena, and the one of them is (a) the transformation of human communication; ordinary communication is transformed into an exotic phenomenon: from now we communicate only with those who are far away. Modern loneliness, which can be characterized as a need and at the same time as a collapse of communication with a close friend, leads to an excessive use of communication with distant persons, but such communication is a surrogate. A person now communicates, dealing with those who are far away - in space, in time or in any other way. When a person ceases to know his 
closest people who enter his sphere of life, his love is directed only at those who are far away, in the remotest corners of the planet (priority is given to the rebels in the Far East or Latin America). Instead of love for relatives, we choose long-distance love: having blocked solidarity with those who are near, the modern individual prefers empathy with the distant ones. But precisely because of this the modern man gets what he tried to avoid - a stronger feeling of loneliness (Marquard 1995: 114).

The second phenomenon is (b) the group's conjuncture as a tool against loneliness. In order to avoid loneliness, a person's running into collective is now considered as a medicine against all diseases. In the future, a person should do nothing alone: he should not read, write, work, live, talk or be happy on his own. Even in solitude, someone cannot be alone; everything must be arranged in a team - there is no salvation without a group (Marquard 1995: 115).

Marquard's analysis of group communication and authentic existence in solitude can easily be seen as the variation of Karl Jaspers' idea of communication. Jaspers described several categories that highlight existence: being-for myself, communication, historicity, freedom, faith, etc. Existence is best highlighted in communication. According to Jaspers, there are two types of communication: inauthentic communication and existential or authentic communication. How different are they?

Inauthentic communication means that people are only forced to communicate, i.e. merely engage in practical activities. A person has to go through this stage of communication, but in that stage of relationship, an individual cannot become himself and cannot find satisfaction. It is precisely that dissatisfaction which forces a person to seek 'true communication'.

Existential communication is possible only when 'I, who expresses himself, can oppose himself to another and to the whole world' (Jaspers 1932: 51). According to Jaspers, the condition of true communication is human loneliness. It means conscious preparation for a possible existence, which becomes authentic only in communication (Jaspers 1932: 51). The perception that each ' $I$ ' contradicts to the others and forms a preparatory stage for existence and communication is important. The peculiarity of existential communication lies in the fact that it cannot be the communication between many people. A communicative act always involves only two components: true communication, according to Jaspers, is a 'love-fight'. Such communication is called to overcome the fragmentation of people, their abruption from each other because the true being is always 'to be with another one. Only through communication a man can come to transcendence. It is easy to see here that communication becomes a kind of substitute for religious communication. Therefore, for Marquard, religion is a positive form of loneliness. For believers God is always here, even when nobody is near.

Marquard points out another two phenomena that are important for such culture: $h u$ mour and education (Marquard 1995: 121). Humour is the lightness, which arises from melancholy, and it allows us to live 'inspite of all', namely: humour maintains an integral disposition with respect to oneself, and therefore, the distance from our own loneliness, it helps to avoid too high expectations. Who is satisfied with just the successful 'supercommunication', he condemns himself to loneliness. The more a person can be alone, the less lonely he is. Education also belongs to the culture of loneliness. It does not mean knowing everything but rather the ability to notice and enjoy something that is not so obvious. It is the ability to enjoy books, paintings and music. Education is a training to be able to obtain additional, unobtrusive benefits and can compensate for loneliness - learning the art of life to be alone, which means not feeling alone. Education is a guarantee of the ability to be alone. The most important question is how it is possible and, in general, if it is possible to turn the burden of solitude into pleasure, 
i.e. the question of ability to the culture of loneliness. Because it is untrue that people can live without solitude. In addition, loneliness cannot be achieved momentarily: there is a need for certain abilities.

\section{REQUIREMENT FOR POSITIVE LONELINESS}

Nevertheless, even in modernity positive loneliness is possible. Marquard insists that such experience was known for Medieval mysticism: Meister Eckhart introduced the word 'loneliness' (Einsamkeit), which determines positive experience, a positive feeling of being alone. First of all, in the Middle Ages the word 'loneliness' had an opposite meaning to loneliness and isolation. It was simply the translation of the Latin word 'unio', unio mistica - a mystical unity with God, and such 'loneliness' (Ein-samkeit) meant an intensive communication between a human being and God. During the course of time, the meaning of loneliness as the unity with God was secularised and finally was transformed into a complete loneliness and the feeling of being apart from everyone. The contemporary meaning of this word is absolute loneliness. But even now, the positive experience of loneliness is still possible because of the existing demand on loneliness (Marquard 1995: 116). Marquard specifies three forms of loneliness. The first of the forms is sceptical loneliness. The greatest skeptic of modernity, French philosopher Michelle de Montaigne formulated and substantiated the method of philosophical skepticism. A critical assessment of Christian dogmatism and religious morality allowed the thinker to pave the way for new ideas. Montaigne was concerned not only about the truth of science and the opinions of the authorities but also emphasised the dialectic of opinions, multiplicity. By stressing the diversity of views on nature and people, Montaigne sought to free a man from the bending of dogmatic thinking, the yoke of medieval prejudices and customs. He understands philosophy as like it was in Ancient Greece. Philosophy, in this tradition, is the 'most valuable of all arts, the art of living well' (Montaigne 1992: 124).

Michelle de Montaigne, when ending his public career, returned to his loneliness, solitude. Sitting in his own castle's tower he gave himself for reading and writing: he wrote about his experiences without any final verdict - this suffocates personal freedom, and that is the major achievement of a skeptical doubt. Marquard writes: 'Freedoms are the result of the separation of powers. An appreciation of these freedoms is found not in the philosophy of principles but in skepticism. This appreciation affects, at the same time, the role played by skeptical doubt; as the separation even of those powers that we call our convictions, skeptical doubt is an appreciation of the separation of powers. Skepticism's doubt is not absolute perplexity but is rather a manifold sense of the isosthenes diaphonia (evenly balanced disagreement), the balance of not only of conflicting dogmas but also of conflicting realities-which by that very fact (divide et liberaliter vive!) allows individuals freedoms and vouchsafes them the relief from the absolute that is also and above all provided, as Hans Blumenberg has shown, by the separation of powers in myth' (Marquard 1989: 17). Loneliness for a skeptic is a chance for thinking and noticing. Guided by own thoughts and hiding behind a joker hat that covers his skeptical ability to loneliness, the skeptic remains beyond communication and confirms himself. In ancient Greece, skeptics have never formed a single school - they are most likely to be lonely philosophers practicing skepticism. At the same time, this is one of the most mysterious philosophical positions because it is not entirely clear how this position is realized in life if we understand philosophy as a way of life. What is the type of lifestyle that skeptics offered? First of all, it is a life without conventions, in its pure nature, with absolute indifference to what people consider desirable or impertinent, good or bad, which leads to a perfect inner peace, 
lack of care. Skeptics did not have any dogmas. It is precisely because of this indifference that skepticism is a great alternative to consumer culture. According to Marquard, 'Skeptics deal, in other words, with the inevitability (due to our mortality) of traditions; and what is known - usually, and with the status of the usual - in those domains, they know too. Thus, skeptics are not those who as a matter of principle know nothing; it is just that they do not know anything that is a matter of principle. Skepticism is not the apotheosis of perplexity; it is simply a bidding "farewell to matters of principle" (Marquard 1989: 15). The second positive form of loneliness is scientist's loneliness, because it is necessary for scientists. Without loneliness (Einsamkeit) science is impossible, even if today some are trying to deny it. Disconnection, loneliness does not make science a private sine cura, but thanks to loneliness, science becomes an isolated room in which an explosive charge of knowledge is developed (Marquard 1995: 118). The last positive form is walker's loneliness. A lonely walk on city streets or in nature eliminates total communication and allows a lonely walker to hide and become invisible. Just like an invisible hat, such a walk indicates the need for human loneliness and hides a walker from the tribunal of communication. And this tribunal of communication is a characteristic feature of modernity (Marquard 1995: 118-119).

\section{CONCLUSIONS}

Z. Bauman identifies consumption as an archetype of solitude, even when it happens to be conducted in a company. For the sociologist, the market is an absolute sovereign which decides all destinies. O. Marquard offers to understand contemporary loneliness as inauthentic, untrue loneliness. That is why consumption is a part of inauthentic communication and it proves inability of the modern individual to be alone.

For the consumer commodity market is very easy to throw away wastrels out of the game of consumption. But this position of loneliness can be considered as an ability to learn to be in solitude, or, in other words, to accept the positive solitude. Religion, humour and education can help to deal with it. But the most important is that beside positive forms of loneliness, such as loneliness of a scientist or a walker, skeptical loneliness forms an alternative way to consumption, a unified stream of modernity which does not recognise the otherness. Skeptical loneliness is life beyond that what is offered by consumers and life beyond any dogmas. It is freedom and, at the same time, an opposition to the sovereign of the consumer commodity market.

Received 18 March 2018

Accepted 7 November 2018

\section{References}

1. Bauman, Z. 2007. Consuming Life. Cambridge: Polity Press.

2. Bielskis, A. 2014. Nešventas Sakramentas. Ideologija, tikèjimas ir išlaisvinimo politika. Vilnius: Demos kritinès minties institutas.

3. Blumenberg, H. 1985. Work on Myth. Cambridge: MIT Press.

4. Cox, H. 2016. The Market as God. Harvard University Press.

5. Die Fragmente der Vorsokratiker. Griechisch und Deutch von H. Diels. Herausgegeben von W. Kranz. 9. Auflage, Bd. I. 1960. Berlin: Weidmannsche Verlagsbuchhandlung.

6. Habermas, J. 1984. Theory of Communicative Action. Volume One: Reason and the Rationalization of Society. Transl. by T. A. McCarthy. Boston, Mass.: Beacon Press.

7. Habermas, J. 1987. Theory of Communicative Action. Volume Two: Lifeworld and System: A Critique of Functionalist Reason. Transl. by T. A. McCarthy. Boston, Mass.: Beacon Press.

8. Jaspers, K. 1932. Philosophie. Bd. 2. Berlin: Springer.

9. Marquard, O. 1989. Farewell to Matters of Principal. Philosophical Studies. Oxford University Press. 
10. Marquard, O. 1995. Skepsis und Zustimmung. Stuttgart: Phillip Reclam jun.

11. Montaigne, M. de. 1992. The Complete Essays of Montaigne. Stanford: Stanford University Press.

12. Rousseau, J.-J. 1992. The Reveries of the Solitary Walker. Transl. by C. E. Butterworth. Indianapolis/ Cambridge: Hackett Publishing Company.

13. Schwarzkopf, S. 2011. "The Political Theology of Consumer Sovereignty. Towards an Ontology of Consumer Society”, Theory, Culture \& Society 28(3): 106-129.

LINA VIDAUSKYTE்

\title{
Alternatyvos vartotojiškai kultūrai, arba skeptiškos vienatvès žavesys
}

\begin{abstract}
Santrauka
Sociologo Zigmunto Baumano knygose, pavyzdžiui, „Vartojamas gyvenimas“, vartotojų prekių rinka analizuojama kaip iggavusi absoliutaus suvereno požymių. Rinka visagalè ir vartotojiškumas, kaip nepaliaujama takios modernybès tẻkmė, neša viską su savimi. Nèra tokios žmogiško gyvenimo srities, kurios nebūtų nuplovęs šitas srautas. Z. Baumanas rinkos poveiki aprašo naudodamas politologijos sąvokas ir kartais apgailestauja, kad šis suverenas išmeta iš savo „valstybès“ tuos netikèlius, kurie neturi teisès joje gyventi. Nelaimèlių, iškritusių iš šio srauto, sociologas beveik neanalizuoja. Tiesiog jie pasirodo kaip tam tikras periferinis elementas, kuris paryškina rinkos ekonomikos poveikį: rinka nèra visiems palanki. Kartu ima atrodyti, kad nebèra jokios išeities iš šios beprotybès. Viskas, įskaitant žmonių santykius, yra viso labo tik vartojimas. Tai suvereno absoliutizmas. Rinkos mitas išaiškinamas iki galo: šioje padètyje nebèra ko dar atsiklausti. Ką reiškia iškristi iš vartotojų rinkos? Ką gali ši vienatvès pozicija suteikti? Straipsnyje svarstomos vartojimo, komunikacijos ir vienatvès temos išryškinant alternatyvias pozicijas vartojimui.
\end{abstract}

Raktažodžiai: suverenas, vartojimas, rinka, skepticizmas, vienatvė, komunikacija 